The Southeast Asian Journal of Midwifery Vol. 4, No.2, October, 2018, p: 46-58

E-ISSN: 2476-972X

P-ISSN: 2476-9738

\title{
Psychosocial Barriers of Unmet Need Among Woman of Reproductive Age
}

\author{
Ajeng Hayuning Tiyas ${ }^{1}$, Mochammad Anwar ${ }^{2}$, Umu Hani Edi Nawangsih ${ }^{3}$ \\ ${ }_{1,2,3}$ Faculty of Health Sciences, University of 'Aisyiyah Yogyakarta
}

\begin{tabular}{l}
\hline ARTICLE INFORMATION \\
\hline Article Trace \\
Submission: April 03, 2018 \\
Final Revision: July 10, 2018 \\
Available online : October 20, 2018 \\
\hline
\end{tabular}

Key Word :

Unmet need, contraception, psychosocial barriers.

\section{Contact:}

ajenghayuning@gmail.com

\begin{abstract}
A B S T R A C T
Women with unmet need are those who are fecund and sexually active but are not using any method of contraception but do not want to conceive either to prohibiting or limiting pregnancy. The unmet need increases the risk of maternal mortality from unwanted pregnancy and unsafe abortion. The percentage of unmet need in Yogyakarta exceeds the national average percentage and Kraton District is the highest region of unmet need in Yogyakarta.

Objective: Exploring in-depth information on the barriers of women of reproductive age to use contraception leads to unmet need behavior in terms of psychosocial aspects

Method: This research was qualitative research with a phenomenological approach. The informants were taken by purposive sampling technique with criterion sampling strategy. The main informants were 7 women with unmet need and supporting informants as many as 11 people. Data collection techniques used in-depth interview and document study. Data analysis using thematic analysis.

Results : Various themes were found to address psychosocial barriers, personal barriers were the main barriers behind women to behave unmet need, including lack of understanding of appropriate contraceptives and unwanted pregnancy risk, weak motivation in using contraception, negative perceptions of contraception, low perceptions of fertility, high self-efficacy against pregnancy prevention strategies and positive coping mechanisms against the risk of pregnancy are undesirable.

Conclusion: Personal barriers are the main obstacles for women of reproductive age to behave unmet need. It needs effective counseling optimization, emphasis on impact and risk of unmet need and strengthening of motivation to use modern contraception in order to increase the sustainability of contraception use and prevent drop out and unmet need for contraception.
\end{abstract}




\section{INTRODUCTION}

Population issues in Indonesia are very complex, namely the large population with high population growth rates, but the quality of resources is low and distribution is uneven. A population of Indonesia has doubled over almost 40 years and is projected to be 259.8 million by 2020 (Bapenas, 2013).

One reason for the large population in Indonesia is the high total fertility rate (TFR), which is 2.6 per woman of reproductive age (IDHS, 2012), and one cause of high TFR is an unmet need. Percentage unmet need in Indonesia at $11.4 \%$ (IDHS, 2012). Unmet need is the percentage of married women aged 15-49 years who do not use contraception but do not want to get pregnant within the next 2 years or do not want to have another child, experience an unwanted pregnancy, or who are in postpartum with an unwanted pregnancy (Bradley et al 2012). Unmet need is great potential for the occurrence of unwanted pregnancy and unsafe abortion, this condition will risk the occurrence of complications in pregnancy, labor, and childbirth (Mujiati, 2013).

The Indonesian government has actually launched various programs to deal with population issues, one of which is through the National Family Planning program (Pusdatin, 2014). One of the efforts is to improve access to services, provide counseling and IEC (Information, Education, Communication), and reorient the strengthening of Post-natal contraception and long-term birth control methods (Ditjen Bina Gizi \& KIA, 2013). However, the program is considered not optimal seeing one of BKKBN's strategic targets has not been fulfilled, namely unmet need of $9.91 \%$ in 2019 (BKKBN, 2015).

Unmet need percentage in the city of Yogyakarta has always been the highest of all regions in the Special Region of Yogyakarta ( $11.40 \%)$, and from fourteen subdistricts in Yogyakarta City, Kraton District is a region with the highest percentage unmet need reached $21.31 \%$ (DIY BKKBN, 2017 ). This is certainly a matter where the city of Yogyakarta is the center of the capital of the Special Region of Yogyakarta and based on the results of the Yogyakarta City RKPD in 2016 shows the level of education of the community is in good category seen from the very high literacy indicator reaching $98.5 \%$ and adequate social welfare height saw from the human development index reached 80.5 (DIY RKPD, 2016). It becomes a matter of contradiction where the characteristics of a society with high social education and does not guarantee the behavior of people in family planning.

The results of the preliminary study showed the main reasons for women behaving unmet need in Kraton Subdistrict is due to concerns about the side effects caused, besides that anxiety about future health conditions due to the influence of contraception makes them prefer not to use modern contraceptive methods.

Various studies have suggested that women fulfill their contraceptive needs, including limited choice of methods, contraceptive misinformation, and concerns about side effects (Campbell et al, 2006). Other studies corroborate the reason women do not use contraception due to their lack of knowledge and problems with their own methods (side effects, concerns about health conditions, and difficulties in using the method) (Sedgh et al, 2007). Korra (2002) adds to the main reason for unmet need is a negative perception of family planning itself, psychological conditions such as worries about side effects plus feelings of infertility and feeling less likely to become pregnant, as well as the frequency of irregular sexual intercourse make women's low acceptance of contraception (Korra, 2002).

In addition to psychological reasons, other interpersonal and social factors also influence, the results of previous studies suggest that husband's agreement about contraception is closely related to the use of contraception by the wife (Casterline, 2001). Psychosocial factors are strongly related to people's negative perceptions of contraception, these factors influence the motivation of individuals to use contraception (Easterline, 1975 in Emens, 2008).

Previous research on the causes of unmet need is still superficial and only involves a number of variables as predictors of the causes of unmet need, research that explores more deeply about the causes of unmet need has not been done, so that researchers are 
interested in delving deeper into what barriers women of reproductive age face and become unmet need.

\section{METHOD}

\section{Research design}

The research method used in this study was a qualitative method with a phenomenological approach. The phenomenological approach was chosen because experience and subjective perceptions of each woman differed, these experience and perception would influence motivation, perceptions, and behavior of the use of contraception so a phenomenological approach was made to understand this. This research was conducted in the District of Kraton, Yogyakarta began in May 2017 until February 2018.

\section{Research subject}

The sample in this study was taken by purposeful sampling technique with a criterion sampling strategy because the research subject was chosen with certain criteria that were in accordance with the research objectives. The criteria in question are: 1) women aged 15 to 49 years, 2) do not use modern contraceptive methods (pills, injections, IUDs, implants, MOW / MOP, condoms, MAL) 3) do not want to get pregnant either to delay or limit pregnancy at least in the next 2 years, 4) fecund 5) women with unintended/unwanted pregnancies 6) postpartum women with pregnancies that are not / have not been desired, 7) Women with unmet need that does not experience disability or impaired function that can interfere with interactions during the interview process.

The number of informants in the study reached a saturation of 18 people consisting of 7 fertile age women as the main informants, and 11 other people as supporting informants, including 7 husbands of women with unmet need, 1 PLKB coordinator (family planning field officer), 2 PPKBD people, and 1 Puskesmas (Community Health Center) coordinating midwife, this technique is a form of source triangulation, it used as an effort to increase data credibility.

\section{Data collection technique}

Data collection techniques carried out was indepth semi-structured interview techniques. The in-depth interviews lasted for 60 minutes to 150 minutes in each informant. To explore information from informants, researchers conducted probing (extracting in-depth information) with interpersonal communication techniques.

In addition to in-depth interviews, document studies were also conducted as a form of triangulation of methods to obtain more accurate and credible data. The documents obtained were then analyzed, compared and integrated (synthesis) to form a systematic, integrated and intact study (Moleong, 2016). The documents that were studied in this study were official documents in the form of family data collection reports, RW level participant data collection reports, PWS KIA-KB Kraton Health Center reports, Pelkon report (Recording and Reporting of Contraception Services) and Dallap (Recording and Reporting of Field Control) BKKBN Yogyakarta and DIY Province.

\section{Data analysis}

The data analysis in this study used thematic analysis, namely the analysis carried out by identifying themes that were patterned in a phenomenon. These themes were identified, inductively encoded from raw qualitative data (interview transcripts) or deductively based on the theory and results of previous studies (Boyatzis, 1998, in Poerwandari, 2001).

The stages in the data analysis process were carried out as follows: 1) compiling a transcript of in-depth interviews 2) making coding/keywords from each statement relevant to the focus of the study 3 ) grouping the coding into various categories and determining themes 4) interpreting information 5) the researcher returns to the informant to clarify the interview data 6) new data obtained when validating informants is combined into the transcripts that have been compiled (Colaizzi, 1978 in Afiyanti, 2014).

\section{RESULTS}

Eight themes were obtained to answer the research objectives and three additional themes that complement the results of the study.

Theme 1. Lack of knowledge about appropriate family planning needs and the risk of unwanted pregnancy

The results of in-depth interviews with informants showed that most of the informants 
had sufficient knowledge about the concept of family planning including understanding, goals, benefits, and types of family planning. But the knowledge of conditions and family planning needs that are appropriate, the ideal time to reproduce, the risks to pregnancy and the impact of the risks of unmet need were not fully understood.

They were not sure about the modern contraceptive methods they have used, whether they were in accordance with their conditions and needs. The lack of confidence in the contraception used caused dissatisfaction with the method used and then caused them to drop out as family planning acceptors, which then continued to be unmet need behavior. Drop out as a family planning acceptor was not accompanied by a decision to regulate fertility that was clear whether you want to get pregnant again soon, want to postpone pregnancy or even want to limit pregnancy. Uncertainty about the decision to regulate fertility causes them to doubt when the right time to reproduce.

The impact of family planning dropouts which then continued to be unmet need behavior was not fully realized by some informants. The risk of the possibility of an unwanted pregnancy was not realized by the informant. Unconsciousness of the risks of pregnancy results in a lack of understanding of the risks of complications that may occur in cases of unwanted pregnancy.

"...I don't think about it (abortion, baby blues), if bleeding and labor are stuck, maybe yes, but if it doesn't mind at all (abortion, baby blues)..." (P2)

\section{Theme 2. Weak motivation in using modern contraception}

Unmet need is closely related to weak motivation to regulate fertility, especially if there are fewer benefits. Motivation to use contraception also depends on the choice of partner fertility. The majority of informants (five people) had fertility options to limit births and the rest were willing to postpone pregnancy for at least the next two years.

Although they had a desire to delay or limit births, they said they had no motivation and intention to use modern contraception for various reasons. Weak motivation in using contraception was also caused by an unpleasant experience with modern contraception that has been used before.

"... from the beginning, I never used modern family planning and there was no desire to use it ..." (P3)

"...no I will not, I don't want to, I've tried many kinds of contraception, but nothing was suitable with me ..." (P1)

\section{Theme 3. Negative perceptions of modern contraception}

Rejection of the use of contraceptive methods is the most for reasons of side effects, both short and long term. In addition, some informants refused to use contraception because it would worsen their current health conditions and worried about invasive actions carried out from several methods offered.

Disorders due to side effects caused not only in the form of physical disorders but also disruption of the role of a wife in the household. Some informants said that the effects of prolonged spotting could not fulfill their obligations as wives. This is reinforced by the triangulation of sources from husbands that the side effects of spotting from a three-month family planning program give a feeling of discomfort to the husband. The inconvenience caused by the side effects is not only in the form of a psychological disturbance in the obligations in the household but also in relation to the obligation to perform worship, informants were not sure when spotting whether they can perform worship (prayer).

The number of complaints against modern contraception makes informants have the perception that modern family planning is considered more likely to cause health problems than the benefits.

"...I've experienced prolonged spotting... I was not comfortable, I wanted to pray but confused, I doubt what menstruation was not, I could pray or not ..." (P4)

\section{Theme 4. Low perceptions of fertility}

Fertility perceptions become the initial perception behind a person to behave in unmet need. The interview results showed that most informants doubted their fertility conditions, especially informants who entered the age of reproductive age, they were not sure whether they could still be pregnant or not at this time. They assume that their age was not in the fertile category due to irregular menstruation, the 
condition which ultimately forms a low perception of their fertility that they were infertile and feel less likely to become pregnant.

Feeling less likely to become pregnant was not only felt by older reproductive-aged informants, some young reproductive-aged informants felt less likely to conceive for reasons of abstinence, and had strong control in preventing pregnancy with a periodic abstinence method.

"...I doubt my age can still be pregnant or not, my period is irregular now ..." (P1)

"...I rarely have sexual relations with my husband, my husband comes home once a week and we have a commit ..." (P3)

\section{Theme 5. The high self-efficacy of pregnancy prevention strategies carried out}

All informants used natural birth control methods as a strategy to prevent pregnancy. Natural birth control methods that were used include methods of interrupted calendar and intercourse (coitus interruptus). Not only using one natural contraceptive method, but some informants also use more than one method to be more convincing and reduce the risk of failure, especially if they use calendar contraception and doubt the right fertile time, they will use other additional methods such as interrupted intercourse.

Although the natural birth control method has a high risk of failure, informants believe that the method they were doing now is effective in avoiding pregnancy (self-efficacy). This belief was supported by a strong commitment and high discipline from the couple that makes them believe that the method they were currently doing is the most effective and better than modern contraceptive methods. This belief was reinforced by personal experience and other people's experiences that they are not pregnant even if they do not use modern contraception.

"... my husband must follow and according to me, so far there is no problem, my husband doesn't have a problem, because only that it's safe ..." (P7)

"... those who do not have contraception also don't get pregnant, so it is safe, right..." (P5)
Theme 6. Strong coping mechanisms against the risk of pregnancy are not desirable

All informants had their own strategies in preventing pregnancy through natural birth control methods, and they realized that the strategy had a high risk of failure, so that at first they experience anxiety about the risk of pregnancy that might occur. However, because of the high self-efficacy of the strategies they did, in the end, they had a positive coping mechanism for the risks and impacts of unmet need. When faced with the risk of unwanted pregnancy they consider it was a gift and destiny of God that must be well received. Praying and being submissive was a form of informants' effort in facing the risk of pregnancy. Positive acceptance of the risk of unwanted pregnancy is one of the reasons they continue to behave in unmet need.

\section{"... I worried, but the rest I pray and just give up ..." (P6) \\ "... of course worried, but if we were given again, let's just consider it's God's gift ..." (P7)}

\section{Theme 7. Lack of a husband's role in using contraception}

Husband's approval is one of the factors of the family level that is very influential on female contraceptive use. The patrilineal culture which the majority adopted by the tribe in Indonesia made men the head of the family, which would determine the decisions taken by each family member including the decision to make family planning.

Some informants said that husbands did not give permission to use contraception for various reasons. Another thing that was supportive was the wife's concern with the method of contraception or feeling unsuitable, while the husband feels uneasy if his wife suffers from the side effects of using contraception.

"... I was prohibited from using it (modern contraception) by my husband, he asked me to use natural contraception only ..." (P5)

"...I felt compassionate for my wife, she has used a variety of things (modern contraception) but nothing to match ..." (S4) 


\section{Theme 8. Variation in social barriers}

In addition to obstacles that come from personal and interpersonal, social barriers also become one of the aspects that affect women to behave in unmet need. Based on the results of in-depth interviews, the social obstacles faced were the existence of negative information about family planning and religious prohibitions to use modern family planning.

Negative information about family planning was derived from the negative experiences of others about family planning, and from mass media, including the publication of research results related to family planning side effects on health. In addition, social barriers were also obtained from the misperceptions of several informants regarding religious views. Some informants refused to use a particular family planning program because they were still hesitant about the law using contraception. In addition, the advice of religious leaders, especially Catholics to use natural contraception, was a strong reason for women of reproductive age to choose not to use modern contraception, this was reinforced by the results of source triangulation from the PLKB and PKKBD.

"...the result of the Obgyn doctoral dissertation at UGM, just came out yesterday and published in $K R$, said that if hormonal contraception can trigger brain tumors, and many side effects, so I am more confident to not use ... " (P3)

"...other religions such as Catholics, priests here do not recommend modern contraception, but still open space for their followers if they want to use modern contraception, unmarried couples are given marriage counseling like premarital counseling before, one of which is taught about natural contraception, such as basal temperature, calendar, basically the point is to suggest using natural contraception ..." (PLKB)

\section{Theme 9. Expectations for future contraceptive methods}

The choice of contraception does not meet the expectations and desires of Fertile Age Couples. Various perceived obstacles raise hopes and desires for improvement from modern contraceptive methods that exist today.
Some expectations from informants wanted modern contraception with minimal side effects, strengthening male birth control programs, providing more varied male contraceptive methods, emphasizing counseling on the management of side effects, and strengthening counseling and motivation for natural family planning.

"... why aren't male contraception variations made like women..." (P3)

"... explained more, if there were side effect what we have to do, for example, we got spotting then what should we do ..." (P1)

"... the strengthening of natural contraception, why not put it into the program so that I don't become a problem (laugh) ... even though the risk is big, but in reality, many people aren't pregnant ..." (P3)

\section{Theme 10. Improper measurement of unmet need}

The results of the study found that the measurement of unmet need was not correct. The results of in-depth interviews conducted showed that there was a lack of understanding from cadres in identifying unmet need criteria. Family planning cadres (PPKBD) are officers who carry out data collection directly in the field.

All fertile age couple that do not use family planning were perceived as belonging to the unmet need category. In addition, there was a lack of understanding of cadres in classifying between modern and natural contraception. Some cadres including PKKBD and PLKB consider that condoms and MAL are not included in modern contraception. In addition, when conducting data collection, the fecund criteria were only seen based on age. Determination of unmet need was also only seen based on the number of living children that exist, not based on fertility choices if you already have two children and do not use contraception it was categorized as an unmet need.

Another problem, participation as family planning acceptors must be indicated by ownership of a family planning card, while not all family planning acceptors have family planning cards, especially condom acceptors, so 
some acceptors who actually use modern contraception were identified as an unmet need because they do not have a family planning participant card.

These findings were reinforced by a document study conducted, in the annual family data collection sheet the measurement of unmet need was only seen based on the history of family planning use, fertility options and reasons for not using family planning, there was no measurement of fecund/infecund criteria, while in the monthly data sheet manual note sheet containing the name and status of contraceptive use and fertility options only.

"... actually the main problem was that, they did not understand, they did not measure it right, the time was also narrow and briefly so they did not have time to ask many questions, I have the data of unmet need that I measure myself, my own initiative... while I see ... until November there were only nine people, but this is the one who only came to the Puskesmas ... " (BD)

\section{Theme 11. Unmet need impact is not significant}

Based on the results of the source triangulation and methods conducted, it shows that there was no significant impact from the high percentage of unmet need. Although the percentage of unmet need is high, it is not always accompanied by high birth rates and a decrease in the number of contraceptive use. There were no data on unwanted pregnancy and abortion due to unmet need. The birth rate actually declined compared to the previous year. The number of contraceptive use has even increased and included areas with the highest percentage of CPR in DIY.

Although the impact of the high unmet need is not significant, the related officers still try to reduce the percentage of unmet need because they are still the target of indicators of performance and program success. Based on the results of the source triangulation and methods conducted, it shows that there is no significant impact from the high percentage of unmet need. Although the percentage of unmet need is high, it is not always accompanied by high birth rates and a decrease in the number of contraceptive use. There were no data on unwanted pregnancy and abortion due to unmet need. The birth rate actually declined compared to the previous year. The number of contraceptive use has even increased and included areas with the highest percentage of CPR in DIY.

Although the impact of the high unmet need is not significant, the related officers still try to reduce the percentage of unmet need because they are still the target of indicators of performance and program success.

"...the problem was that wrongly measuring... then, this unmet need doesn't always end with pregnancy, I don't have the data either ...abortion is not, if any, not because of unmet need of contraception but unwed pregnancy..." (BD)

"...not all unmet need ends with pregnancy, complications and abortion, as I said earlier, for data there is not yet but it can be seen from the birth rate, TFR here is low, we only follow the central government as long as it is targeted and it is still one of the indicators of the success of the family planning program, so we continue our efforts to reduce it, we are still focused on it ..." (PLKB)

\section{DISCUSSION}

Contraception knowledge is a prerequisite for using contraception (Abeka, 2012). Lack of knowledge, especially related to fertility, is one of the obstacles for women to use contraception (Casterline et al, 2000). The Misnaniarti study literature based on the 2012 IDHS data states that one of the factors causing unmet need in Indonesia is the lack of understanding of women of reproductive age about the risk of pregnancy that can occur and the risk of unwanted pregnancy due to not using contraception (Misnaniarti, 2016).

Women with good knowledge of contraception can also behave unmet need. Knowledge alone is not enough to increase the application of a behavior, there are still other factors that influence a person's behavior such as internal factors (intelligence, perception, emotions, motivation, education and so on) and external factors which include the physical (climate, 
human) and non-physical environment (socioeconomic, culture, access to information, and experience) (Notoadmojo, 2003 in Sukmadinata, 2003). So that people with high knowledge can experience an unmet need for family planning

In addition to lack of knowledge, unmet need is closely related to weak motivation to use contraception, because the perceived benefits of using contraception and the chance of pregnancy are felt to be smaller (Casterline et al, 1995 in Bushan, 1997). Motivation to use contraception is also influenced by previous unpleasant experiences due to side effects, an experience will influence the behavior of subsequent health promotion (Pender, 2011).

Poor perceptions of modern contraception and low perceptions of fertility are the main personal barriers that cause a person to behave unmet need. Perception is the main concept in the Health Belief Model that determines a person's health behavior. This perception arises from the individual's belief in illness and the strategies taken to prevent the disease and complications that may occur (Hayden, 2009).

There are 4 main dimensions of the Health Belief Model, namely perceived susceptibility, perceived severity, perceived benefits, perceived barrier (perception of barriers). Then added the construct of other driving factors (cues to action) such as motivation, self-efficacy, interpersonal and social factors (Hayden, 2009). According to the Health Belief Model, a person must first consider himself susceptible to a condition (perceived susceptibility) just to determine a particular health strategy or behavior. Someone who uses modern contraception considers themselves at risk of becoming pregnant so they use contraception to prevent pregnancy. On the other hand, in the case of unmet need, they assume that there is little chance of pregnancy so that it does not require modern contraception. Low perceptions of fertility cause their lack of motivation to use modern contraception (Amy, 2009). The reason is due to age, rarely having sex (abstinence) and irregular menstrual cycles.

Frohwirth et al (2013) study of women who had an unwanted pregnancy abortion in the United States found that the majority of women were convinced and believed they would not get pregnant even without using contraception, they felt immune to pregnancy. These findings provide strong evidence that low susceptibility to pregnancy or infertility perceptions affects the behavior of contraceptive use (Frohwirth et al, 2013 in King, 2015). The separation from a partner for a long time (abstinence) which affects the pattern of sexual behavior is also a cause of unmet need (Woldemicael and Beaujot, 2011).

In addition to the low perception of fertility, the negative perception of modern contraception is also the main reason for unmet need. Rejection of the use of contraceptive methods is the most because of the side effects caused by contraception itself. The perception that often arises is an excessive concern because of the side effects of contraception and fear of specific procedures related to several methods of contraception, these perceptions appear to be based on unconfirmed rumors (Wulifan, 2016 in Canoot, 2016). The same thing was expressed by Van Lith et al (2013) explaining that the main reason that most often appears not to use contraception is fear of side effects (Van Lith, 2013 in Canoot, 2016). The results of the Fahrunnisa (2014) study in Agam Regency, West Sumatra, state that the main cause of women with unmet needs in Indonesia is the perception of potential side effects caused by contraception and health concerns in the future. They claimed to be deterred from the side effects of family planning that make discomfort in the body, such as bleeding, irregular menstruation, frequent abdominal pain, tend to be emotional and other negative perceptions of family planning. In addition, subjective experience that pregnancy does not occur even without using contraception is also one reason women do not use contraception (Fahrunnisa, 2014).

The concept of HBM explains that a person's health behavior (using contraception) starts when an individual understands that the negative impact caused by not using contraception is an unwanted pregnancy, and he is able to perform the behavior (using contraception). Decisions to carry out certain health behaviors are also weighed from how many barriers and benefits are felt, or in other words, which is greater between the perceived barrier and the perceived benefits of using modern contraception (King, 2015). Health Belief Model shows that once the potential threat of pregnancy is known, if the benefits of contraception are felt to be greater than the obstacles it feels, a person will tend to 
use the contraception, but vice versa if the perceived obstacles are greater than the benefits obtained then someone will tend not to use contraception this is the concept of the Health Belief Model to explain the behavior of unmet need for family planning.

The strategy carried out by all informants in preventing pregnancy is to use traditional or natural family planning methods, namely by coitus interruptus, calendar methods and a combination of coitus interruptus methods and calendar methods. The reason the informants used this method was that of their ability to prevent pregnancy, ease the method and there were no side effects on health.

Traditional contraceptive methods such as coitus interruptus and calendar have a high risk of failure because of the need for sufficiently good sexual experience and the ability to calculate the fertile period properly (Aghajanian et al, 2007). The effectiveness of the use of the coitus interruptus method itself also depends on the ability of men (partners) to control themselves, which is removing the penis before ejaculation. The existence of strong commitment and high discipline from each partner gives their confidence in the effectiveness of the strategy in preventing their pregnancy.

Self-efficacy is the last psychosocial level of the HBM concept. Self-efficacy states that to enforce behavior change, a person must believe that he can take action (Glanz et al, 2008). An individual must believe that being involved in certain behaviors will achieve the desired results, and his ability to do that behavior (King, 2015). Research on the relationship between selfefficacy and contraceptive behavior in women suggests that women with low self-efficacy use contraception have feelings of conflict regarding sexual activity they do, which in turn will contribute to ineffective and inconsistent use of contraception and vice versa (Strecher et al, 1986).

Unmet need women involved in this study all experienced anxiety about the risk of pregnancy. However, they have a positive coping mechanism for the risk of unwanted pregnancies, praying and surrender is a form of their coping mechanism. The adequate coping mechanism is a coping mechanism that supports the functions of integration, growth, learning and achieving constructive goals (Stuart, 2007). Adequate coping is based on the ability of the informant to receive a good enough risk of pregnancy. This situation is related to the social and economic factors of the informants where most informants have good social and economic status so that they are better prepared if faced with pregnancy.

In addition to personal obstacles, interpersonal and social barriers are also a cause of unmet need. Poor perceptions of husbands on modern contraception are one of the reasons for the husband's prohibition to use contraception. Research by Sariyati (2015) showed that husband's consent was the most dominant factor in the incidence of unmet need for family planning. Some women decide to behave unmet need because of negative information about contraception both from other people's experiences and reporting in the mass media. The existence of negative stories or rumors heard about contraception can affect the acceptance of informants about contraception.

The behavior of unmet need as a form of the decision not to use contraception is not only caused by personal experience but also because it is based on experiences from other people (Pender, 2011). This is in accordance with the results of a study that revealed that the sources of causes of unmet need were caused by women's own experiences with contraception, friends' experiences, and rumors that were often heard repeatedly in the community (Bongarts, 1995 in Sita, 2003). Incorrect perceptions of contraception from the community are formed from generation to generation. Automatic public perception will directly influence the perceptions of individuals and also partners (Canoot, 2016).

Triangulation carried out in midwives in Kraton Subdistrict is in line with the results of existing research, where women who are afraid of contraception are usually due to hearing other people's stories that are not necessarily true but trusted. It is clear that social influences in the form of models or rumors will influence the beliefs and behavior of individuals in improving health. Negative beliefs can be a big obstacle for women in meeting their contraceptive needs.

In addition, religious affiliation has a strong relationship with contraceptive use, such as the emphasis on natural contraceptive use and the law on using family planning itself (Kirk, 1967 
in Adjei, 2014). Another study by Kelodjoue (2015) in Cameroon, one of the obstacles to unmet need is the interpretation of religion by the community that contraception is prohibited from being used primarily by the Church, Islam is more tolerant where contraceptive use is allowed for certain purposes and methods, except certain Islamic groups assume that contraceptive use is prohibited (Kelodjoue, 2005).

In addition to the theme that answers the research objectives, there are several other facts related to the problem of unmet need. The results showed, in addition to the obstacles faced by women of reproductive age so that unmet need behavior, found several facts related to the problem of unmet need in Kraton Subdistrict, Yogyakarta City, namely the measurement of inaccurate unmet need and the insignificant impact of unmet need on birth rates.

Unmet need is related to the failure of the family planning program in providing family planning services because it is one indicator of the success of the family planning program. The contraception that people want is not available in service units, or in other words, the quality of contraception is below the expectations of the community.

A number of studies related to unmet need in Yogyakarta have been carried out, one of them is the results of Listyaningsih (2016) which examines the concept of unmet need if it is applied in areas with community characteristics such as in the city of Yogyakarta. It was found that the existing concept of unmet need still needs to be studied more deeply, especially when the unmet need is used as an indicator of the performance and success of programs in DIY. This is related to the fact that unmet need does not always end in pregnancy.

The results of these studies are very relevant to the results of this study. Although the percentage of unmet need in the city of Yogyakarta, especially the Kraton Subdistrict, is high the total fertility rate is low. Based on data from the Yogyakarta City Population and Civil Registry Service, the city TFR number of 2.1 means that the average number of children born alive by a woman until the end of her reproductive period in the Yogyakarta Special Region is as much as 2.1. reproduction). This figure has met the 2015
MDG target of 2.1 and even exceeded the national target in 2019, 2.28, and made the Yogyakarta Special Region the region with the lowest TFR in Indonesia (IDHS, 2012). And based on the Puskesmas report the birth rate in Kraton Subdistrict in 2017 decreased from 177 births in 2016 to 144 births in 2017. This needs to be noted that the high unmet need in Kraton Subdistrict is not always accompanied by high TFR rates.

Based on the results of the study, all informants preferred to use natural family planning as a pregnancy prevention strategy compared to modern family planning. Natural family planning is not included in the modern contraception category (except the MAL method). Even though traditional contraceptive methods according to some people are quite effective in preventing pregnancy, from the government side as the program organizer, this method still has a high chance of failing until it ends in pregnancy so that it is not included in the program.

Traditional contraceptive methods also need to be seen and controlled with women characteristics in evaluating the effectiveness of traditional contraceptive methods. Individual factors, such as discipline and unwillingness to have children, are important variables in preventing pregnancy. The use of traditional contraceptive methods will not have the same effect when individual characteristics are different (Listyaningsih, 2016)

Other problems arise when the issue of the unmet need concept is not well understood by family planning caders. Family planning cadres are not able to identify fertile age couple that is in the category of unmet need or not. In addition, the inadequate understanding regarding the identification of modern and natural contraception also influences the identification of unmet need.

In addition, discussions about the unmet need to pay attention to the age of women of reproductive age. The age of the unmet need group needs to be classified, whether it is included in the category of young fertile age couple or old fertile age couple to make it easier to determine target targets and program policy targets. Unmet need for young fertile age couple is very important to consider the level of 
participation, both as new participants and as a target for the type of short or long term contraception. Meanwhile, the old fertile age couple with experience not using contraception that does not end with pregnancy is very difficult to be directed to use one type of contraception even though the contraception is not permanent, so the focus of the program policy is to adapt to the conditions and needs of each couple of reproductive age.

In addition, discussions on unmet need also need to pay attention to the age of the last child and the number of children owned. If the age of the last child has entered adolescence, then the fertile age couple decides not to use contraception is not too worrying. The age of the last child who has grown up indirectly will describe the age of the categorized fertile age couple as an old fertile age couple.

Unmet need as an indicator of the performance of population institutions needs to be studied further and deeper. Unmet need targets in a region with the characteristics of a society that has a high level of education and socioeconomic such as in the Kraton Subdistrict, Yogyakarta City, will be difficult to reduce. However, if the performance indicator uses TFR, the population target can be achieved. The high unmet need is not always and immediately related to the failure to decrease the rate of pregnancy or birth. Existing Unmet need will not necessarily end in pregnancy or birth. If unmet need continues to be used as an indicator of the performance and success of the population institution program, some conceptual adjustments need to be made, such as the classification of the age of women and the age of the last child.

\section{CONCLUSION}

Various themes were found related to psychosocial barriers for women of childbearing age with unmet need behavior, including poor understanding of contraception and the impact of unmet need, weak motivation in using modern contraception, negative perceptions of modern contraception, low perceptions of fertility, self efficacy high on the strategies carried out in preventing pregnancy positive coping mechanisms for the risk of unwanted pregnancy, lack of role and involvement of husbands in the use of modern contraception, negative information about family planning and misperception of religious understanding of the concept of family planning.

In addition to the eight themes that answer the research objectives, three additional themes outside the research objectives have been found but can support and complement the results of the research analysis, namely expectation of contraceptive methods in the future, inaccurate measurement of unmet need and insignificant impact of unmet need on birth rates Kraton.

Some suggestions that can be concluded from the results of the study include:

1. For further researchers

a. Using combination research methods to produce more comprehensive facts and research results can be generalized statistically.

b. Measuring the magnitude of the relationship between unmet need behavior and unwanted pregnancy, especially in areas with community characteristics such as in the city of Yogyakarta.

c. Assess more deeply whether the current concept of unmet need is the right indicator as an indicator of the success of programs so that program planning can really measure the problems that exist and be right on target.

2. For stakeholders

a. Reviewing the concept of unmet need as a performance indicator and program given that the target of unmet need in areas with community characteristics such as in the city of Yogyakarta is very difficult to reduce, and the fact that unmet need does not always end in unwanted pregnancy. If unmet need continues to be used as an indicator of program performance and success, it is necessary to make some adjustments to the concept, such as classifying the age of the woman and the age of the last child to determine whether the women are included in the criteria for infecund or not.

b. Use more rational performance indicators such as TFR, because the high unmet need does not always affect the failure to decrease the rate of pregnancy or birth.

Multiple contraceptive methods or combinations with natural methods need to be considered in 
the modern contraceptive program with an emphasis on the control of women characteristics (education, social, economic level) so that they can evaluate the effectiveness of traditional contraceptive methods because they are proven to prevent pregnancy effectively.

\section{BIBLIOGRAPHY}

Abeka, Seith Odiwuor. (2012). Family Planning and Women's Unmet need in Kibera Slums, Nairobi. Thesis. Master of Arts in Gender and Development. The University of Nairobi. Nairobi.

Adjei, D., JO Sarfo, M. Asiedu, \& IA Sarfo. (2014). Psychosocial Factors Affecting Contraceptive Usage: A Case of Unmet need s in Ghana. European Scientific Journal, 10 (15), 84-93.

Afiyanti, Yati, \& IN Rachmawati. (2014). Metode Penelitian Kualitatif dalam Riset Keperawatan Edisi ke 1. PT Raja Grafindo Persada. Jakarta.

Aghajanian, AA, Mehryar, H., Delavar, B., Kazemipour, S., \& Zinab, HE (2007). Continuing Use of Withdrawal as a Contraceptive Method in Iran. Canadian Studies Population, 34 (2), 179-190.

Amy, JJ \& Tripathi, V. (2009). Contraception for women: an evidence-based overview. British Medical Journal, 2009;339:b2895.

Badan Kependudukan dan Keluarga Berencana Nasional (BKKBN). (2015). Rencana Strategis Badan Kependudukan dan Keluarga Berencana Nasional Tahun 2015-2019. Jakarta. BKKBN.

Badan Koordinasi Keluarga Berencana (BKKBN) Daerah Istimewa Yogyakarta. 2017. Analisis \& Evaluasi Hasil Pelkon \& Dallap. Yogyakarta. BKKBN DIY

Badan Perencanaan Pembangunan Nasional (Bapenas), Badan Pusat Statistik (BPS), United Nations Population Fund. (2013). Proyeksi Penduduk Indonesia (Indonesia Poplation Projection). Jakarta. BPS

Bushan, Indu. (1997). Understanding Unmet need, Working Paper Number 4. Baltimore. The John Hopkins School of Public Health Center for Communication Programs.
Campbell, M., NNS Hodoglugil, \& M. Potts. (2006). Barriers to Fertility Regulation: Review of the Literature. Studies Family Planning, 37 (2), 87-98.

Canoot, Griet. (2015). Unmet need for Family Planning: Clients and Organizational Barriers and Opportunities in Access to Family Planning in Sub-Saharan Africa A Systematic Review. Dissertation. Master of Medicine in Medicine. Universiteit Gent. Gent.

Casterline, JB, SW Sinding. (2000). Unmet need for Family Planning in Developing Countries and Implications for Population Policy. Population and Development Review, 26 (4), 691-723.

Casterline, JB., Sathar, ZA., U1 Haque, M. (2001). Obstacles to Contraceptive Use in Pakistan: A Study in Punjab. Studies Family Planning, 32 (2), 95-110.

Direktorat Jenderal Bina Gizi dan Kesehatan Ibu dan Anak. (2013). Rencana Aksi Nasional Pelayanan Keluarga Berencana 20142015. Jakarta. Kementerian Kesehatan RI.

Emmens, Amie. (2008). Research Report: Perceived Fertility Regulation Cost and Contraceptive Use in Nepal. Population Study Center. Institute of Social Research. The University of Michigan.

Fahrunnisa.,

A.

Meilinda. (2014). Penyebab Unmet

need KB dari Sudut Pandang Budaya Minangkabau di Nagari Lambah Kecamatan Ampek Angkek Kabupaten Agam. The Southeast Asian Journal of Midwifery, 1 (1), 22-28

Glanz, K., Rimer, B, \& Viswanath, K. (2008). Health Behavior and Health Education Theory Research and Practice 4th Edition. Jossey-Bass A Wiley Imprint. San Fransisco.

Hayden. Joanna. (2009). Chapter 4 Health Belief Model. Burlington. MA. Jones and Bartlett Publisher.

Kelodjoue, Samuel. (2015). Trends and Determinants of Unmet Need for Family Planning in Cameroon: The Role of Socio-Cultural Context. Sociology Studies, 5 (1), 39-52.

King, Aisha Saliha. (2015). Attitudes and Interventions Towards a Novel Male Contraceptive: A Health Belief Model Approach. Senior Projects Fall Paper 59.

Korra, Antenane. (2002). Attitudes toward Family Planning and Reason for Nonuse 
among Women with Unmet need for Family Planning in Ethiopia. ORC Macro. Calverton, Maryland, USA.

Listyaningsih, Umi., Sumini, \& S.Satiti. (2016). Unmet need: Konsep yang Masih Perlu Diperdebatkan. Jurnal Populasi Pusat Studi Kependudukan dan Kebijakan UGM, 24 (1), 72-90

Misnaniarti., D. Ayuningtyas. (2016). Unmet need for family planning in Indonesia and the Policy Strategy of Intervention in Several Countries. International Journal of Reproduction, Contraception, Obstetrics and Gynecology, 5(6), 16801685.

Mujiati, Inti. (2013). Pelayanan KB Pasca Persalinan dalam Upaya Mendukung Percepatan Penurunan Angka Kematian $\mathrm{Ibu}$. Buletin Jendela Data dan Informasi Kesehatan Semester II 2013. Kementerian Kesehatan RI. Jakarta

Pemda Daerah Istimewa Yogyakarta. (2016). Rencana Kerja Pembangunan Daerah Daerah Istimewa Yogyakarta (RKPD). Pemda Daerah Istimewa Yogyakarta

Pender, NJ, CL Murdaugh, \& Parsons, MA (2011). Health Promotion in Nursing Practice (6th Edition). Boston, MA: Pearson.

Pusat Data Informasi Kemenkes RI. (2014). Situasi dan Analisis Keluarga Berencana. Jakarta. Kementerian Kesehatan RI.
Puskesmas Kecamatan Kraton. 2016. Profil Kesehatan Kecamatan Kraton tahun 2016.

Sariyati, S., S. Mulyaningsih, \& S. Sugiharti. (2015). Faktor yang Berhubungan dengan Terjadinya Unmet need KB pada Pasangan Usia Subur (PUS) di Kota Yogyakarta. Jurnal Ners dan Kebidanan Indonesia, 3 (3), 125-129.

Sedgh, G., Hussain, R., Bankole, A, \& Singh, S. (2007). Woman with an Unmet Need for Contraception in Developing Countries and Their Reasons for Not Using a Method. Occasional Report No.37. New York.

Sita, Sahle. (2003). Assessment of the Magnitude and Determinants of Unmet Need for Family Planning among Currently Married Women in Urban and Periurban Community in Awasa, Southern Ethiopia. Thesis. Master of Public Health. Addis Ababa University. Addis Ababa.

Strecher, V., McEvoy DeVellis, B., Becker, M., \& Rosenstock, I. (1986). The Role of SelfEfficacy in Achieving Health Behavior Change. Health Education \& Behavior, 13 (1), 73-92.

Stuart, G \& Sandra, J. (2007). Buku Saku Keperawatan Jiwa Edisi 4. EGC. Jakarta.

Sukmadinata. (2003). Informasi dan Pengetahuan. Bina Rupa Aksara. Jakarta.

Woldemicael, G \& Beaujot, R. (2011). Currently Married Women with An Unmet need for Contraception in Eritrea: Profile and Determinants. Canadian Studies in Population, 38 (2), 61 -81. 